\title{
Student Achievement assisted Edmodo: An Alternative to Online Learning in the Pandemic Era
}

\author{
Sofia Nida Khoerunnisa ${ }^{1, \text { a) }}$, Puji Lestari ${ }^{1}$ \\ ${ }^{1}$ Universitas Siliwangi \\ 24 Siliwangi Street, Kahuripan, Tawang, Tasikmalaya, West Java, Indonesia, 46115 \\ a)khoerunnisasofia@gmail.com
}

\begin{abstract}
Due to the Covid-19 pandemic, face-to-face instruction in the field of education has been replaced by online learning. As a result, to meet the learning goals, teachers must be innovative and creative while delivering online learning. Student Achievement with Edmodo is one alternate online learning choice. This analysis aims to explain the effects of the introduction of Edmodo-supported Student Achievement, as well as student reactions to this learning, and to provide a single learning method that is successful and can aid teaching and learning experiences for high school mathematics content during the Covid-19 pandemic. This study employs qualitative analysis approaches. The subjects of this research were five students from Tasikmalaya City's State Senior High School. Based on the outcomes of a few experiments, it was determined that the learning experience was enjoyable and aided students' comprehension of the Trigonometry content. Students are pleased with the learning experience provided, and they believe they have made improvements as a result of their participation in the learning. According to the effects of the impact size estimation, the implementation of the Student Achievement learning model is very accurate. Then, for general student assessment, Student Achievement learning with Edmodo is beneficial to introduce in the middle of the Covid-19 pandemic, so that it can be used as a substitute in online learning.
\end{abstract}

Keywords: Covid-19; Edmodo; Learning Media; Student Achievement

\begin{abstract}
Abstrak. Pembelajaran tatap muka langsung yang biasa dilaksanakan dalam dunia pendidikan berubah menjadi pembelajaran daring karena adanya pandemi Covid-19. Oleh karena itu, diperlukannya inovasi dan kreativitas guru dalam memberikan pembelajaran daring sehingga tujuan pembelajaran tercapai. Salah satu alternatif pembelajaran daring yang dapat dilakukan adalah Student Achievement berbantuan Edmodo. Tujuan dari penelitian ini adalah mendeskripsikan hasil implementasi Student Achievement berbantuan Edmodo, dan respon peserta didik terhadap pembelajaran tersebut, serta menghasilkan satu kesatuan proses pembelajaran yang tepat guna dan dapat membantu kegiatan belajar mengajar materi matematika SMA pada masa pandemic Covid-19. Metode penelitian yang digunakan dalam penelitian ini adalah metode penelitian kualitatif. Subjek pada penelitian ini adalah 5 orang peserta didik Sekolah Menengah Atas (SMA) Negeri di Kota Tasikmalaya. Berdasarkan hasil uji coba terbatas, diperoleh kesimpulan proses pembelajaran tersebut menarik dan membantu meningkatkan pemahaman peserta didik dalam materi Trigonometri. Peserta didik merasa senang dengan proses pembelajaran yang diberikan dan peserta didik merasa ada kemajuan setelah mengikuti pembelajaran tersebut. Berdasarkan hasil perhitungan effect size, penerapan model pembelajaran Student Achievement sangat efektif untuk diterapkan. Kemudian untuk evaluasi secara umum dari peserta didik, pembelajaran Student Achievement berbantuan Edmodo efektif untuk dilaksanakan di tengah pandemi Covid-19, sehingga dapat digunakan sebagai alternatif dalam pembelajaran daring.
\end{abstract}

Kata kunci: Covid-19; Edmodo; Hasil Belajar Siswa; Media Pembelajaran Online 


\section{INTRODUCTION}

Indonesia's education system is focused on classroom instruction, and students are required to attend school every day. The Covid-19 pandemic is widespread in Indonesia, with cases increasing rapidly, prompting the government to advise all Indonesians to limit their practices to their homes. One of the effects of the Covid-19 pandemic has been the closing of vast colleges, madrasas, universities, and Islamic boarding schools (Setiawan, 2020). As a result, face-to-face learning has given way to online learning. Teachers are expected to amuse current technologies, and teachers' ingenuity and imagination are required in terms of delivering online learning so that students are not discouraged and want to learn, not just tasks so that learning goals are met. To accommodate teaching and learning events, a learning medium that can be used in online learning is needed.

A teacher's use of learning media is critical when presenting the subject matter to pupils (Putra, Fauzan \& Habibi, 2020). The teacher will illustrate the content more proportionally by using educational media (Borovcnik \& Kapadia, 2009). Learning media assists educators with communicating knowledge or subject matter to students to meet learning objectives. The presence of learning media is suggested as a way to enhance the learning experience (Syawaluddin, Gunarhadi, \& Rintayati, 2019). Learning media plays a vital part in the teaching and learning process for teachers (Setiyani, Putri \& Prakarsa, 2019; Wijayanti, Hasan, \& Loganathan, 2018). Students are more excited about studying mathematics as they are exposed to learning media. Learning media must be appealing and realistic to improve students' interest in learning and pursue the learning process (Setiyani, Putri \& Prakarsa, 2019). The role of learning media in teaching goals is to involve students cognitively and emotionally, which means that by using learning media, students try to practice deeper learning and are interested, inspired, and pleased with the learning (Syawaluddin, Rachman, \& Khaerunnisa, 2020).

Science and technology are evolving at a fast pace to keep up with the times. Technological advancements are very beneficial in the field of education; one consequence of technological progress is the availability of various forms of learning media that can aid the learning process and enable students to easily embrace and appreciate the subject matter. Educators may use a variety of learning media to deliver subject matter when dealing with the Covid-19 pandemic. Paper, nonprint, and interactive media are all forms of educational media (Omodara \& Adu, 2014). Learning media such as Virtual Classroom (Google Classroom, Edmodo, Schoology, school E-Learning, etc.), Video Conference (Zoom, Google Meet, Webex Meet, etc.), e-books, learning videos shared via YouTube, chat apps (Whatsapp, Telegram, Thread, etc.) and so on are used in online learning.

Digital classrooms are a category of media that can be conveniently used and maximized. A virtual classroom is an online learning experience that can be web-based, portal-based, or softwarebased (Sohibun \& Ade, 2017). Virtual Classroom will handle the traditional face-to-face learning experience remotely, beginning with monitoring student enrollment, presenting the subject matter, 
and administering assessments. The Learning Management System (LMS) is one of several interactive classrooms that can be used. LMS is a piece of software or software that is used for administrative purposes, reporting, content search, task records, and supplying materials for online teaching and learning events that are linked to the internet (Ellis, 2010). In Indonesia, the most common LMSs are Google Classroom, Edmodo, e-learning used by some universities, and so on (Irfan, Kusumaningrum, Yulia, \& Widodo, 2020).

The LMS used in this analysis is Edmodo. The explanation for using Edmodo is that its appearance is similar to Facebook, so students can conveniently use it during the teaching and learning period. This platform is similar to Facebook, but it is more private and safe since only educators who build and maintain accounts and who obtain a group code can enter and enter the group (Kongchan, 2008). Edmodo is very easy to use; users can access it from smartphones, laptops, tablets, and other devices by visiting the Edmodo website or downloading the app, which is available in the Apple App Store and the Google Play Store. Edmodo is a social networking site that allows teachers and students to communicate, share, and learn in a secure environment (Trust, 2017). Educators may use Edmodo to build class groups, join topic communities, and connect colleagues to their network (Trust, 2015).

To optimize the use of Edmodo as a learning medium, a learning syntax is needed such that teaching and learning practices are more concentrated. In other words, a learning paradigm was used in this Edmodo application. Student Achievement was the learning paradigm used in this research. The Student Achievement learning model is based on the Students Teams Achievement Division (STAD). STAD is one of the most important cooperative learning approaches, and it has had a positive impact on a variety of classes and topics (Alijanian, 2012). According to Slavin (2005), the key idea of STAD is to encourage learners to support one another and assist other students in mastering the skills learned by the teacher. STAD can motivate students to enhance their performance (Slavin, 2015). STAD will boost student learning motivation by exchanging and sharing knowledge to improve, offer support, and hold students accountable for their work (Rusdin, Widodo, \& Maruto, 2020). This model was chosen because it is easy and practical enough to be used in online learning. Due to the restricted deployment of the model for students, it is not possible to split students into different classes so that the model can be applied individualized. The STAD learning model was updated by researchers into Student Achievement.

Trigonometry is a topic that many students struggle with. The first stages in studying trigonometry are daunting for most students (Blackett \& Tall, 1991). Furthermore, Chigonga (2016) discovered that students often misunderstand the sine, cosine, and tangent of an angle when the value is negative, struggle to define the related angles in different quadrants, and reach invalid conclusions. It is possible to assume that students continue to struggle with trigonometric material. The material used in this analysis is trigonometry, which includes the trigonometric ratio of right 
triangles, trigonometric ratios for angles in different quadrants and associated angles, sine and cosine laws, and trigonometric functions using unit circles. This material was selected to help students understand complex Trigonometry materials as well as to make the teaching and learning experience more interesting and enjoyable.

Wrahatnolo, Wibawa, and Wahono (2019) discovered that using Edmodo in conjunction with a curriculum model would increase student learning outcomes. Furthermore, the findings of Silitonga and Wu's (2019) study indicate that STAD-type cooperative learning with Edmodo will increase the efficiency of classroom learning; in this study, Edmodo was used after face-to-face learning. Since the introduction occurred during the Covid-19 pandemic, there was no face-to-face learning in this analysis. According to the above definition, Edmodo-assisted Student Achievement learning is intended to be a learning breakthrough that can pique students' interest in learning Trigonometry content. This analysis aims to explain the outcomes of the introduction of Edmodo supported by Student Achievement, describe the students' responses to this learning, and create an effective learning method that can aid teaching and learning activities for high school mathematics content during the Covid-19 pandemic.

\section{METHOD}

The research approach used in this study is qualitative research methods. Qualitative analysis is designed to gather knowledge about the status of an existing illness, specifically the state of the symptoms at the time the research was performed (Arikunto, 2012). Certain measures, such as students' ability to participate in learning until the end, were included in the selection of subjects in this sample. Five students from Tasikmalaya City's class X Senior High School learned the subjects. In this analysis, the learning flow of the Student Achievement learning model supported by Edmodo is as follows: (1) the instructor offers to learn; (2) the teacher assigns tasks to be completed independently with separate questions for each individual; (3) students post their responses in the Edmodo virtual classroom; and (4) students compare their friends' answers and have the right to ask questions before they understand; (5) The teacher administers a quiz that can be viewed on Edmodo within the time frame specified; (6) The teacher offers an evaluation; and (7) Individual rewards.

Trigonometric survey questions and questionnaires were used in this analysis to gather data. The Trigonometric content evaluation instrument consists of ten items, and the questionnaire instrument used is a student response scale in the shape of a ranking scale with five alternate responses. The data processing methodology used in this study is descriptive. 


\section{RESULTS AND DISCUSSION}

Before introducing the pupil, the first move is to create a virtual class on Edmodo and post a variety of items such as participation, learning videos, conversation content, and quizzes. Since Edmodo is new to students, researchers offer guidance for students who enter Edmodo. Students are given class codes by the researchers. When students log in or create accounts, they enter the class code. As a result, when students successfully establish an account, they are immediately added to the researcher's class. There are no particular issues for students when signing in; it's just that students log in at various hours, and one student logs in by picking an instructor. Researchers, on the other hand, accept this because it has little effect on the access that students would handle.

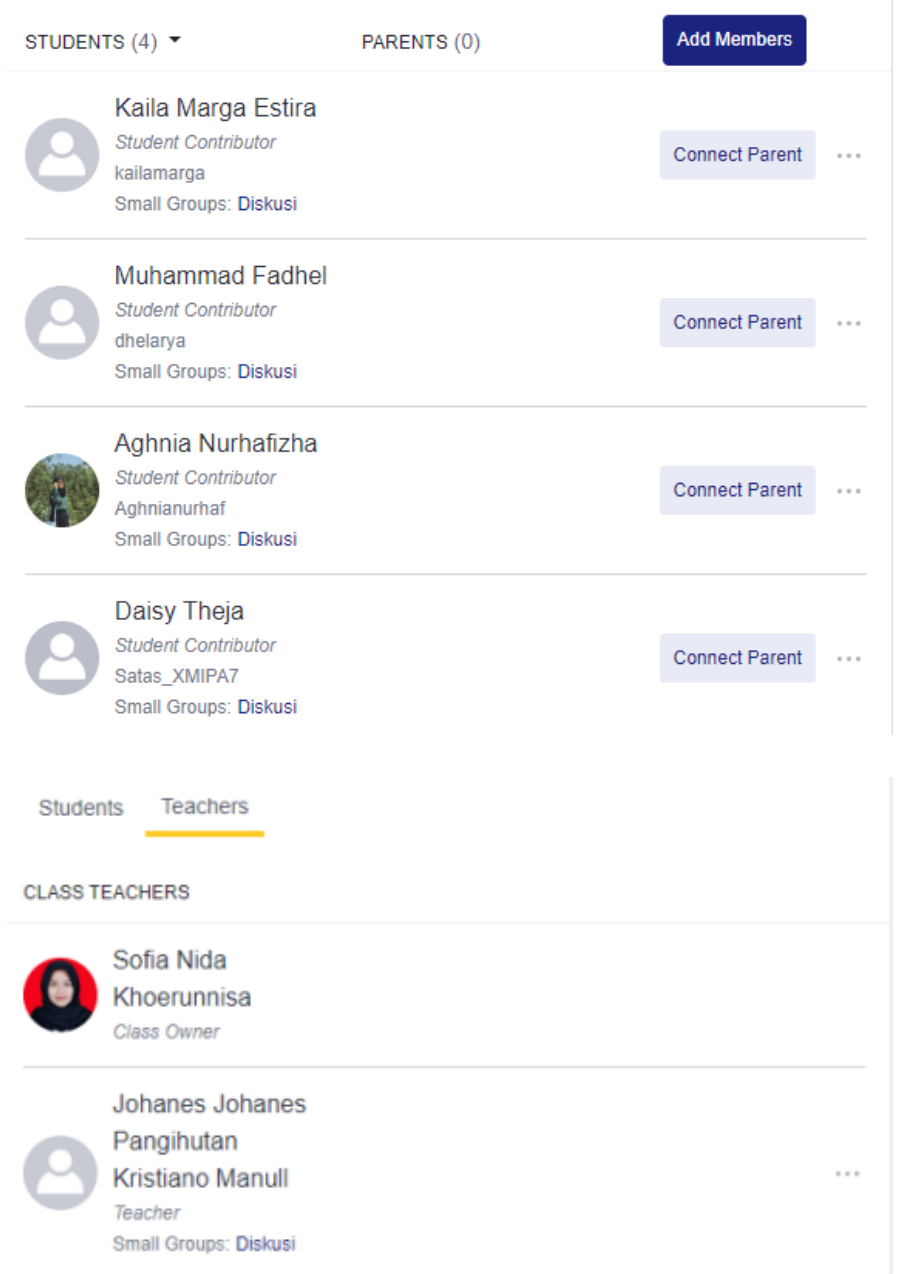

Figure 1. Student Participation in Edmodo Virtual Class

While successfully entering the Edmodo virtual class, students are instructed to scroll down to the Edmodo virtual class so that students fill in the absences first because the absence posts are at the bottom. Following student attendance, Edmodo does not yet have an automated attendance function, so the researchers opted to render manual absences by typing their names. 


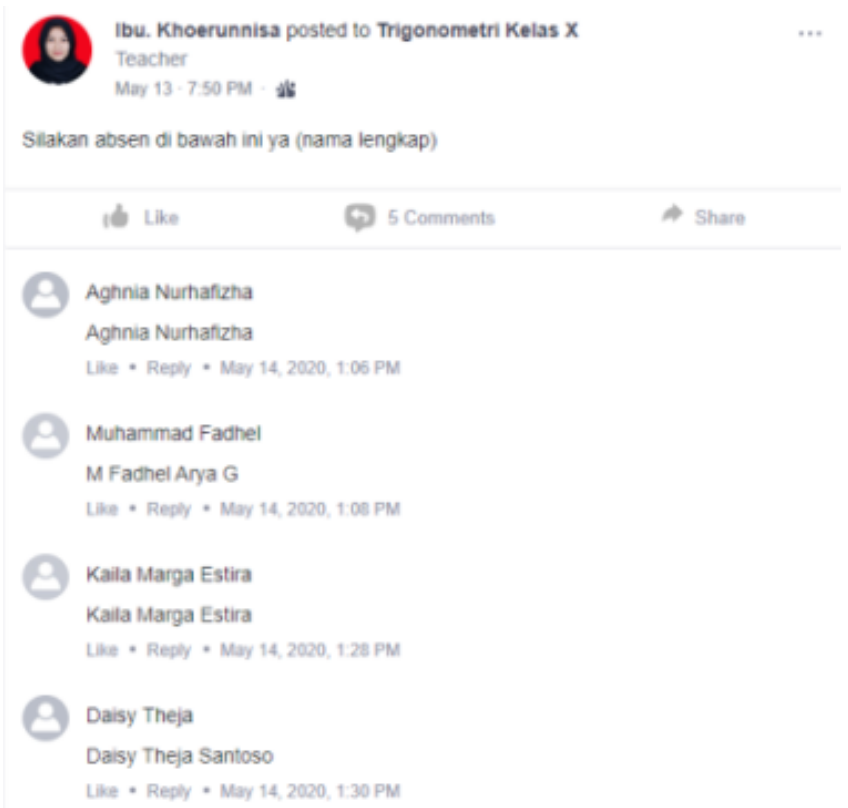

Figure 2. Student Attendance

After students fill in the absences, students are instructed to watch the learning video. The learning video is about Trigonometry which includes material on Trigonometric ratios on right triangles, Trigonometric ratios for angles in various quadrants and related angles, rules of sines and cosines, and Trig functions using unit circles. It is hoped that from the learning video students can understand the material so that they can solve trigonometric problems. The following is a learning video post.

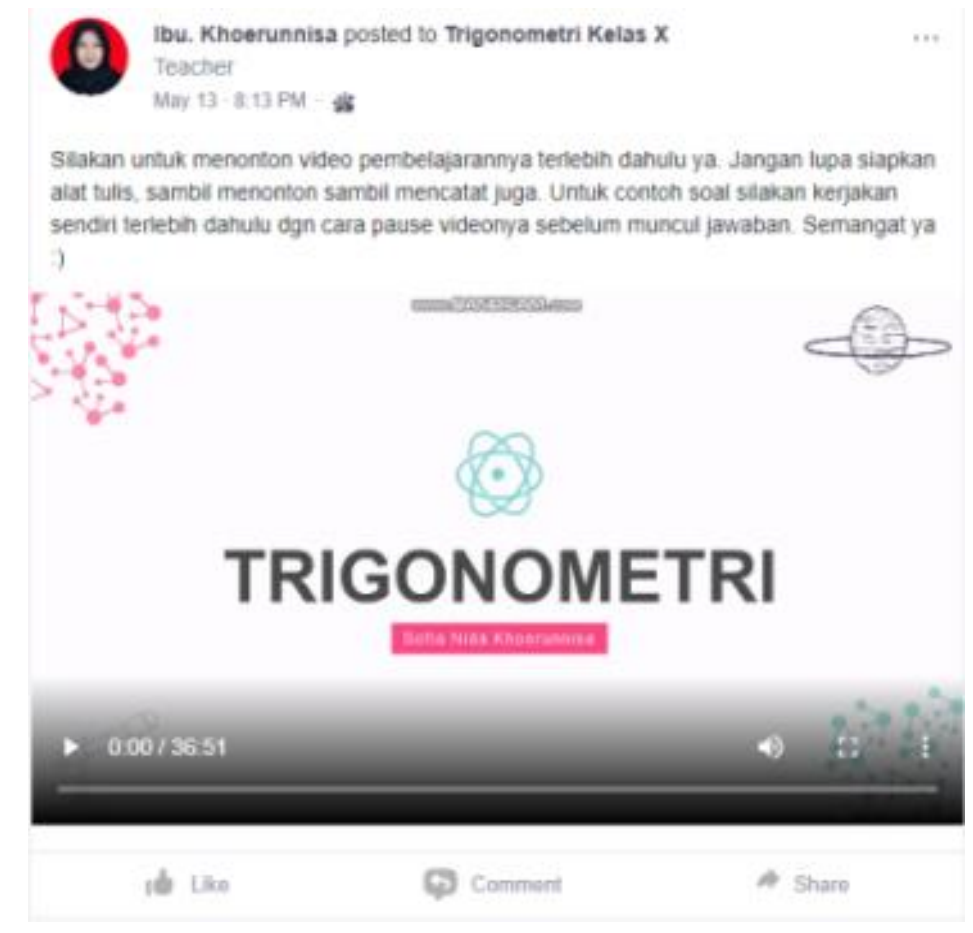

Figure 3. Trigonometry Learning Videos 
Then each student is given an individual assignment to complete, with different questions for each student. As a result, after watching the instructional video, students worked on one of the questions immediately. Since these questions are used as discussion material, it is hoped that students will be responsible for the outcomes of their responses. The questions are required as a PDF file.

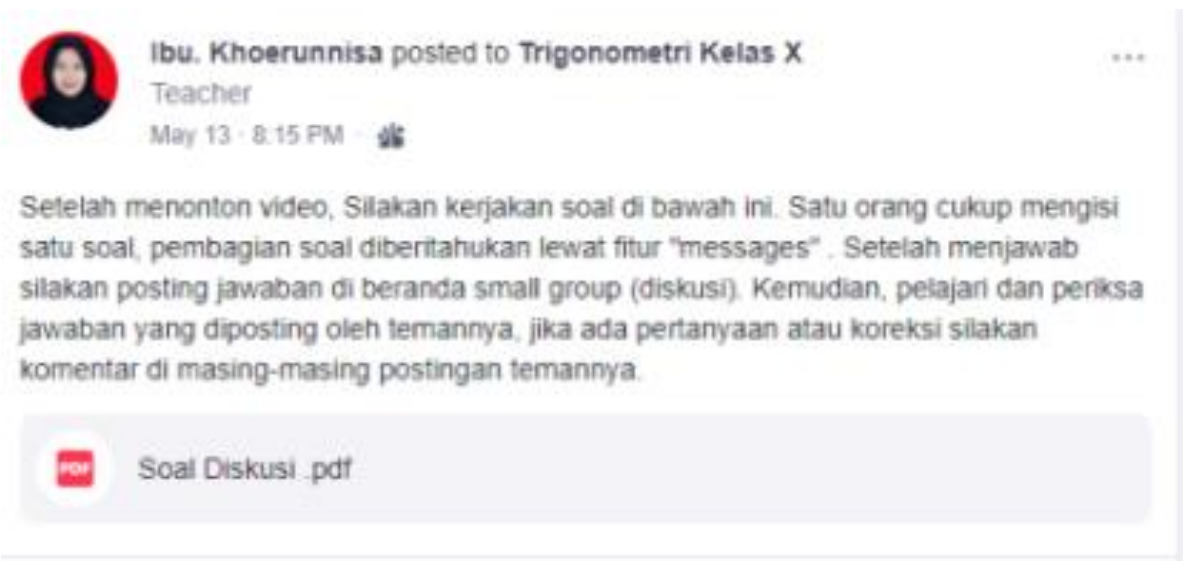

Figure 4: Individual Instructions for Solving One Question

While working on one question, each student is allowed to ask outside the forum if they run into any difficulties. These questions are discussed through the personal "message" feature between students and researchers. The following message features are available on Edmodo.

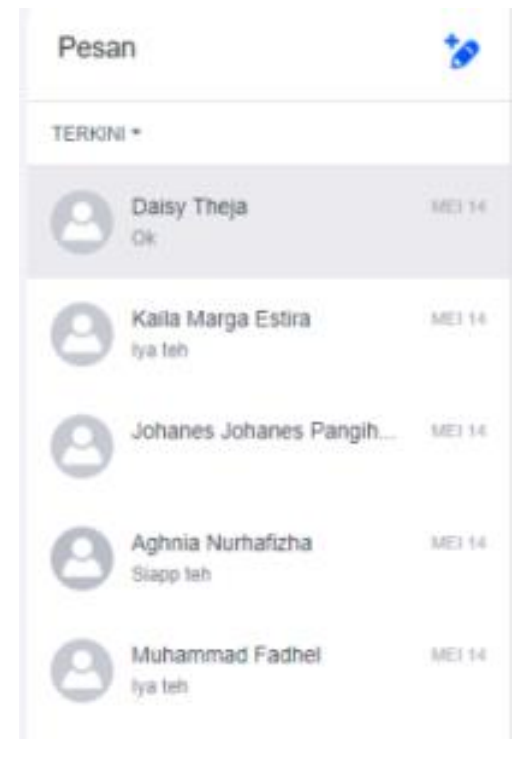

Figure 5. Message Features

The application of Edmodo enables students to actively participate because online learning offers an interactive learning environment, as described by Pratama and Ismiyati (2019). After students have completed one of these questions, they should post their answers in Edmodo's virtual classroom's "Small Group-Discussion" feature. Small-Group is an Edmodo virtual class feature that 
allows all members of the class to form a small group. This small group provides a platform for students to post their responses so that they can be discussed in detail.

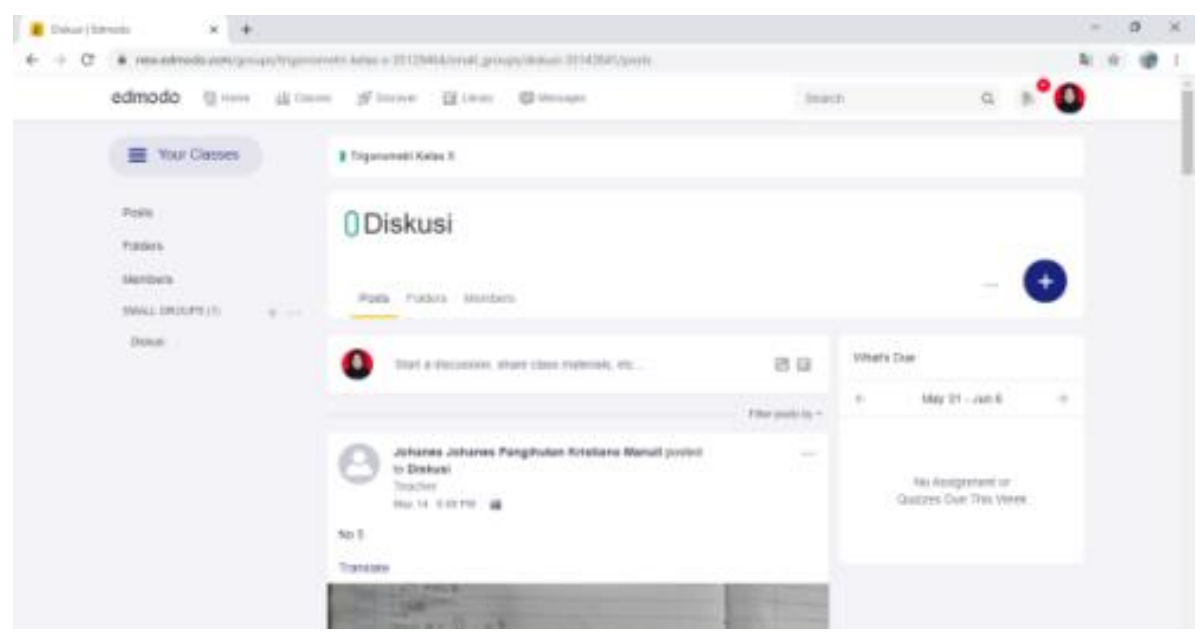

Figure 6. Small Group-Discussion
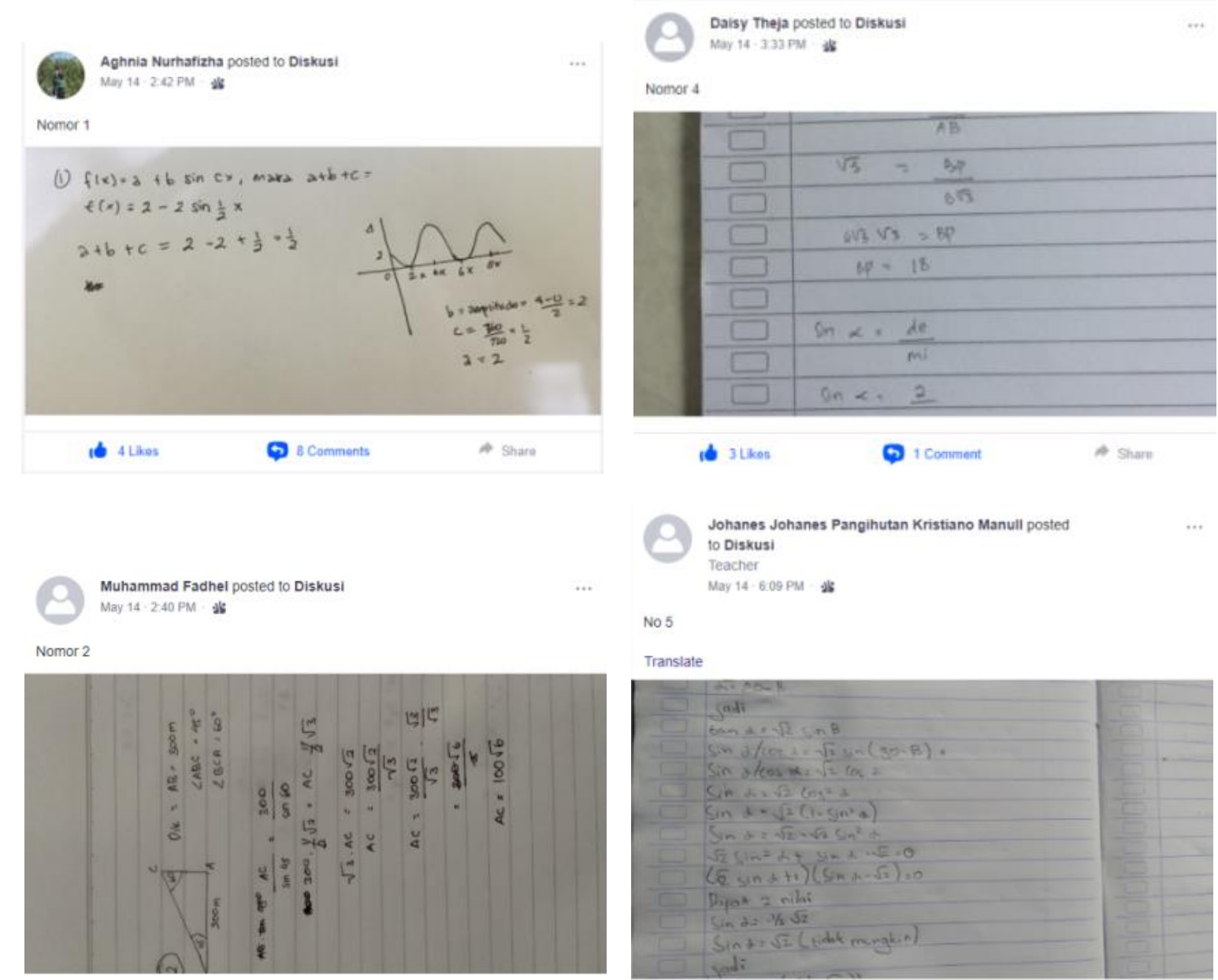

No 5

Translate

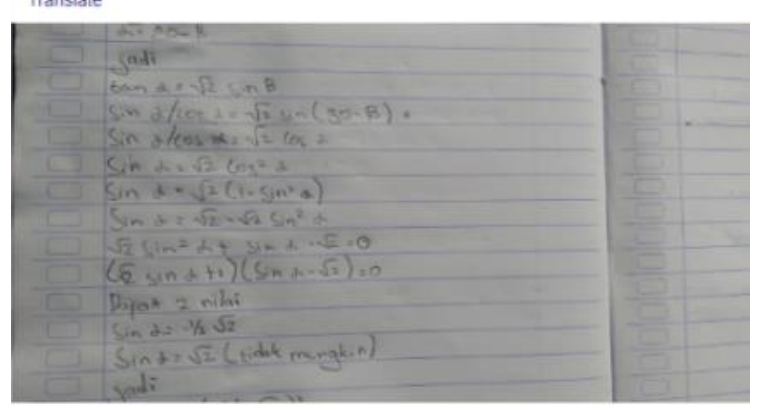

(b) Likes

(\$) 3 Comments

A Share

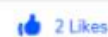

(9) Comment

A Share

Figure 7. Results for Student Responses for Each Question 
Each student's responses to the exam questions all yielded the correct answer. Any of these questions are easily answered by students. Following that, students commented on other friends' question posts if they did not understand anything or did not agree with the friend's response. The researcher must also provide instructions and explanations for the correct answer at this stage. The following are the outcomes of student debates, which seem to be similar to Facebook comments.

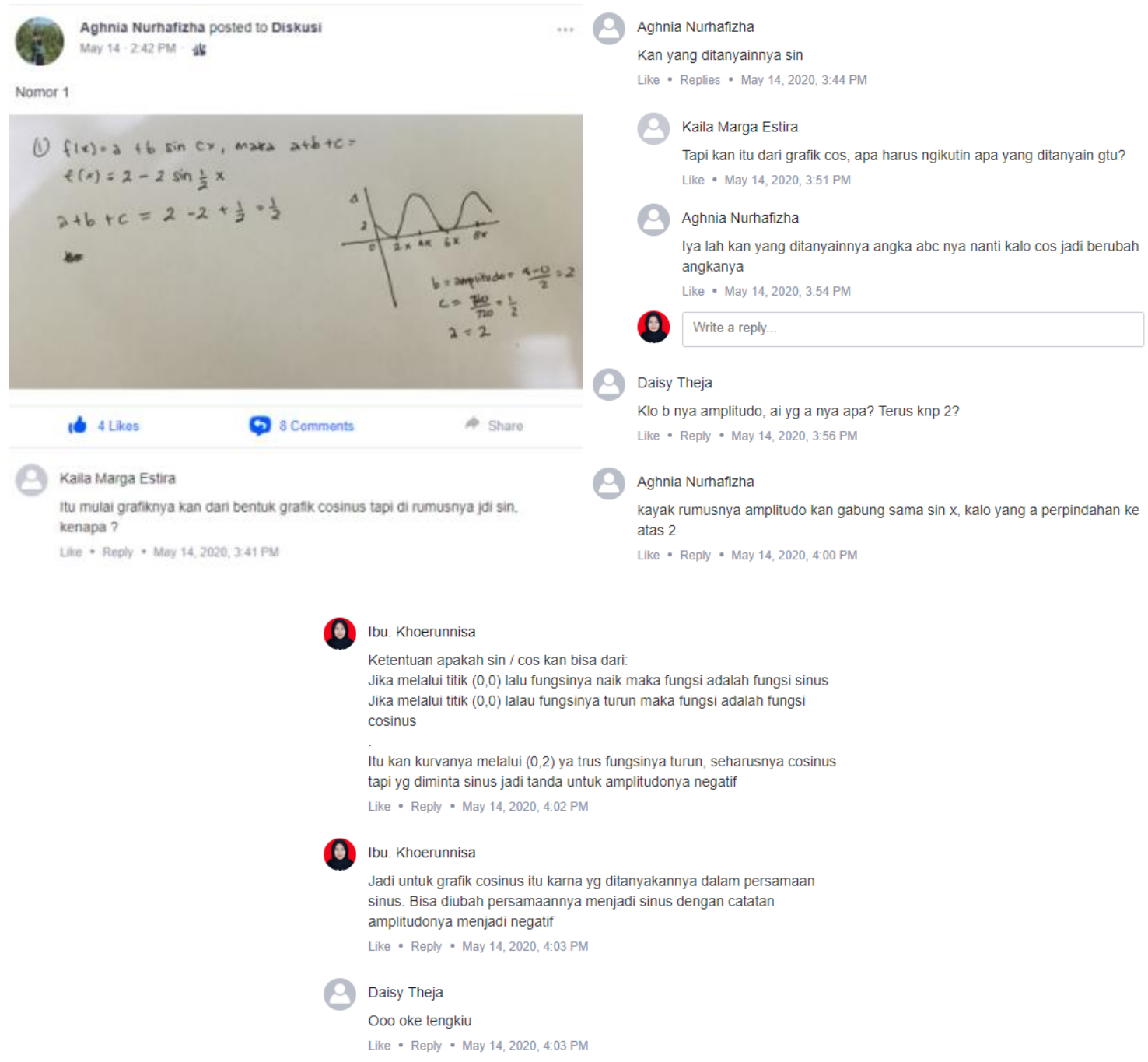

Figure 8. Student Discussion

In the discussion process, students are active in asking questions until they all feel that they understand the answers provided by their peers, and students who work on these answers will be held accountable for the outcomes of their work. This is following the statements made by Rusdin, Widodo, and Maruto (2020). By exchanging and sharing information to enhance, provide feedback, and have the responsibility to do their job, the Student Teams Achievement Division will increase student motivation. Meanwhile, there are no difficulties with numbers 3, 4, or 5, as students understand and agree with their peers' responses. After the discussion, students complete the Edmodo quiz. There are ten multiple-choice questions in this quiz. 


\begin{tabular}{|c|c|c|c|}
\hline Student & Status & Time Submitted $\checkmark$ & Score \\
\hline (9) Aghnia Nurnafizha & Graded & Late May 14, 4.38 PM & $90 / 100$ \\
\hline (9) Munammad Fadhel & Graded & Late May 14, 4.38 PM & $40 / 100$ \\
\hline Daisy Theja & Graded & Late May 14,4:39 PM & $70 / 100$ \\
\hline (9) Kaila Marga Estira & Graded & Late May 14, 4:40 PM & $70 / 100$ \\
\hline 9. Johanes Johanes Pangihutan Kristiano Manull & Graded & Late May 14, 6:39 PM & 801100 \\
\hline
\end{tabular}

Figure 9. Student Quiz Results

The next step is to evaluate and reward students who achieve the highest quiz score. Researchers distribute the quiz's correct answers so that students can double-check their answers and figure out where they made mistakes. The reward will be in the form of a credit of IDR 15,000. This reward has been informed at the previous meeting to increase student interest in learning. According to (Slamet \& Maarif, 2014), the positive impact of reward in learning is that it strengthens the relationship between teachers and students, increases students' attention to mathematics, stimulates and increases motivation to learn mathematics, increases mathematics learning activities, and fosters productive student behavior.

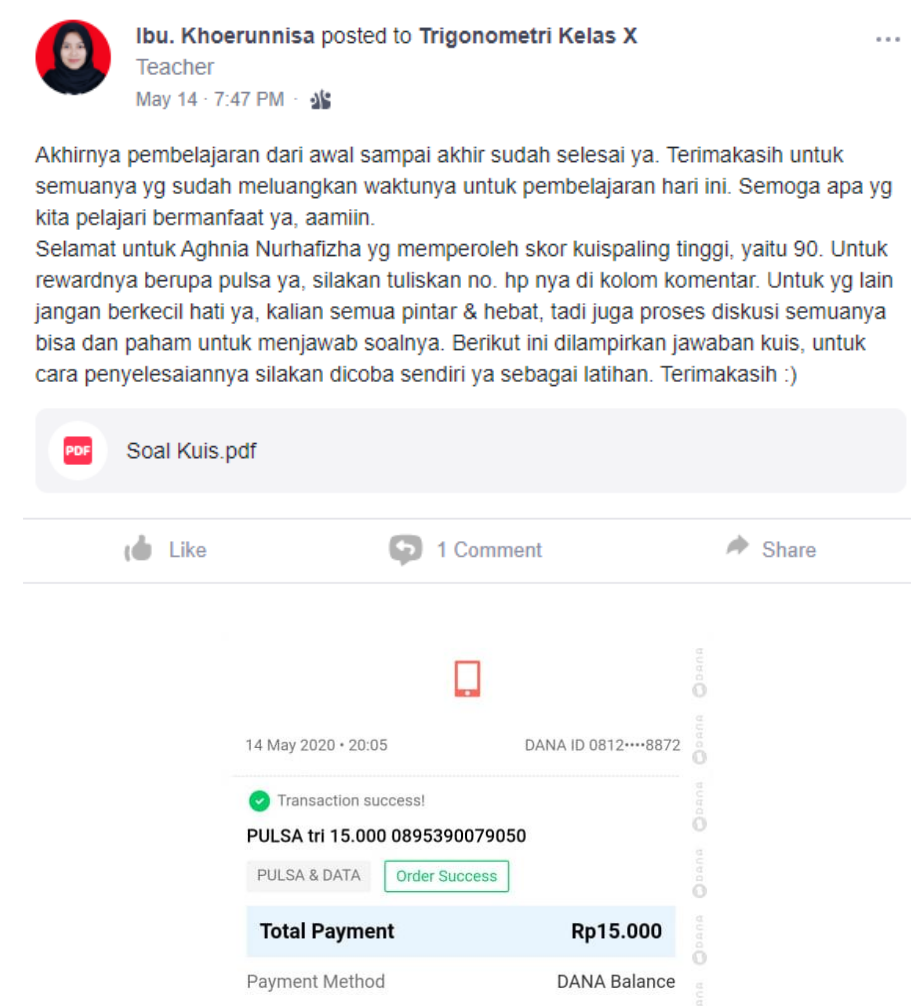

Figure 10. Rewards for Students Who Get the Highest Quiz Score

As an evaluation material, the researcher distributed a questionnaire to students. The purpose of this survey was to find out how students felt about using Edmodo to learn about Student Achievement. The questionnaire is divided into several sections and employs a rating scale. 
According to the results of the student response questionnaire, Mathematics learning Student Achievement with Edmodo received a positive response from students. Student Achievement with Edmodo is a new experience for students, making them more enthusiastic about learning. Edmodo makes students happier and learning more interesting, as well as assisting them in learning the Trigonometry material.

Furthermore, students are enthusiastic about working on different questions for each individual as discussion material, and they are happy to post their responses and receive feedback posed by their peers. Giving students rewards at the end of the learning process encourages them to participate more actively in the learning process. Students feel that Student Achievement learning using Edmodo is more engaging and effective to implement, and it helps them understand the subject matter.

Besides that, Edmodo is easy to use, and students perceive improvement after completing the Edmodo learning process. This is in line with the findings of Silitonga and Wu's (2019) study, which found that cooperative learning from the Student Teams Achievement Division with Edmodo assistance can boost classroom learning efficiency. Moreover, according to research conducted by Wrahatnolo, Wibawa, and Wahono (2019), using Edmodo as part of a learning model will increase student learning outcomes. In addition to distributing questionnaires, an effect size test was conducted to determine the effectiveness of the Edmodo-assisted Student Achievement learning model. In 1988, Cohen's criteria were used to interpret effectiveness (Becker, 2000). The following is the formula for the calculation.

Table 1. Effect Size Calculation

\begin{tabular}{lcccc}
\hline No & Name & Initial Value & Final score & Difference \\
\hline 1. & Aghnia Nurhafidza & 60 & 90 & 30 \\
\hline 2. & Muhammad Fadhel & 0 & 40 & 40 \\
\hline 3. & Daisy Theja & 40 & 70 & 30 \\
\hline 4. & Kaila Marga Estira & 60 & 70 & 10 \\
\hline 5. & Johanes Pangihutan Kristiano Manull & 50 & 80 & 30 \\
\hline & Average & 42 & 70 & 28 \\
\hline
\end{tabular}

effect size $=\frac{\text { different of means }}{\text { standard deviation }}=\frac{28}{22,02}=1,27$

THE CALCULATION RESULT SHOWS THAT THE EFFECTIVENESS IS 1.27 AND THE EFFECTIVENESS IS IN A STRONG CATEGORY. This indicates that the Student Achievement learning model, which is assisted by Edmodo, is very effective. According to 
research conducted by Rusdin, Widodo, and Maruto (2020), the use of learning media as a platform for learning at home for Edmodo's Student Teams Achievement Division is quite effective.

\section{CONCLUSION}

The learning flow of the Student Achievement learning model assisted by Edmodo in this study entails: (1) The teacher provides learning; (2) The teacher gives assignments to be completed individually with different questions for each individual; (3) Students post their answers in Edmodo virtual classroom; (4) Students check their friends' responses with each other and have the right to ask questions until they fully understand (5) The teacher gives a quiz that is accessed on Edmodo within the specified time; (6) The teacher provides an evaluation; and (7) Rewards for individuals. According to the findings of the survey, Student Achievement learning assisted by Edmodo was appreciated by students since this learning process is new learning for students. Furthermore, the learning process is engaging and helps students' comprehension of Trigonometry material. Students are satisfied with the learning process and believe they have made progress as a result of their participation. The implementation of the learning process improves student learning outcomes and achievement in Trigonometry material based on the findings of student test evaluation. Student learning outcomes have improved in both their initial and final grades. Based on the results of the effect size calculation, the application of the Student Achievement learning model is very effective Moreover, for general evaluations from students, Student Achievement learning with Edmodo is effective to be implemented during the COVID-19 pandemic. In conclusion, it is expected that Edmodo can be used as an alternative in teaching and learning activities during the COVID-19 pandemic. Even during a pandemic, we should be able to innovate in learning, particularly in mathematics.

\section{REFERENCES}

Alijanian, E. (2012). The Effect of Student Teams Achievement Division Technique on English Achievement of Iranian EFL Learners. Theory \& Practice in Language Studies, 2(9). https://doi.org/10.4304/tpls.2.9.1971-1975

Arikunto, S. (2012). Prosedur Penelitian : Suatu Pendekatan Praktik (Edisi Revisi). Rineka Cipta.

Becker, L. A. (2000). Effect size ( ES ) - Part I. 1993, 14. http://web.uccs.edu/lbecker/Psy590/es.htm

Blackett, N., \& Tall, D. O. (1991). Gender and the versatile learning of trigonometry using computer software. In Proceedings of the 15th Conference of the International Group for the Psychology of Mathematics Education (Vol. 1, pp. 144-151). Assisi: PME.

Borovcnik, M., \& Kapadia, R. (2009). Research and developments in probability education. International Electronic Journal of Mathematics Education, 4(3), 111-130.

Chigonga, B. (2016). Learners' errors when solving trigonometric equations and suggested interventions from grade 12 mathematics teachers. International Society for Technology in Education.

Ellis, R. K. (2010). A Field Guide to Learning management systems. In International anesthesiology clinics. 
Irfan, M., Kusumaningrum, B., Yulia, Y., \& Widodo, S. A. (2020). Challenges During the Pandemic: Use of E-Learning in Mathematics Learning in Higher Education. Infinity Journal, 9(2), 147-158. http://www.e-journal.stkipsiliwangi.ac.id/index.php/infinity/article/view/1830

Kongchan, C. (2008). How a non-digital-native teacher makes use of Edmodo. In 5th International Conference ICT for Language Learning. Florence.

Manfred, B., \& Ramesh, K. (2009). Research and developments in probability education. International Electronic Journal of Mathematics Education.

Omodara, O. D., \& Adu, E. I. (2014). Relevance of Educational Media and Multimedia Technology for Effective Service Delivery in Teaching and Learning Processes. IOSR Journal of Research \& Method in Education (IOSRJRME).

Pratama, R. A., \& Ismiyati, N. (2019). Pembelajaran Matematika Berbasis Edmodo Pada Mata Kuliah Teori Bilangan. AKSIOMA: Jurnal Program Studi Pendidikan Matematika. 8(2), 298-309.

Putra, R., Fauzan, A., \& Habibi, M. (2020). The Impact of Cognitive Conflict Based Learning Tools on Students` Mathematical Problem Solving Ability. International Journal of Educational Dynamics, 2(1), 209-218. https://doi.org/10.24036/ijeds.v2i1.247

Rusdin, M. E., Widodo, W., \& Maruto, G. (2020). Implementation Cooperative Learning Type STAD Assisted Edmodo in Improving Students' Critical Thinking Skills. Indonesian Review of Physics, 3(1), 30-34.https://doi.org/10.12928/irip.v3i1.1766

Setiawan, A. R. (2020). Lembar Kegiatan Literasi Saintifik untuk Pembelajaran Jarak Jauh Topik Penyakit Coronavirus 2019 (COVID-19). Edukatif: Jurnal Ilmu Pendidikan, 2(1), 28-37. https://doi.org/10.31004/edukatif.v2i1.80

Setiyani, S., Putri, D. P., \& Prakarsa, D. (2019). Designing Camtasia Software Assisted Learning Media Toward Students' Mathematical Comprehension In Numeral Material. Infinity Journal, 8(2), 143-156. https://doi.org/10.22460/infinity.v8i2.p143-156

Silitonga, L. M., \& Wu, T. T. (2019, December). Increasing students' interest and learning achievement using cooperative learning (Students Team Achievement Division) through Edmodo. In International Conference on Innovative Technologies and Learning (pp. 3-13). Springer, Cham. https://doi.org/10.1007/978-3-030-35343-8_1

Slamet, S., \& Maarif, S. (2014). Pengaruh bentuk tes formatif assosiasi pilihan ganda dengan reward dan punishment score pada pembelajaran matematika siswa SMA. Infinity Journal, 3(1), 59-80. https://doi.org/10.22460/infinity.v3i1.39

Slavin, R. E. (2005). Cooperative Learning: Teori, Riset dan Praktik (Cooperative Learning: Theory, Research and Practice). Diterjemahkan oleh Narulita Yusron. Bandung: Nusa Media.

Slavin, R. E. (2015). Instruction Based on Cooperative Learning. In Handbook of Research on Learning and Instruction. https://doi.org/10.4324/9780203839089.ch17

Sohibun, S., \& Ade, F. Y. (2017). Pengembangan Media Pembelajaran Berbasis Virtual Class Berbantuan Google Drive. Tadris: Jurnal Keguruan Dan Ilmu Tarbiyah, 2(2), 121. https://doi.org/10.24042/tadris.v2i2.2177

Syawaluddin, A., Rachman, S. A., \& Khaerunnisa. (2020). Developing Snake Ladder Game Learning Media to Increase Students' Interest and Learning Outcomes on Social Studies in Elementary School. Simulation \& Gaming, 51(4), 432-442. https://doi.org/10.1177/1046878120921902

Syawaluddin, A., Gunarhadi, \& Rintayati, P. (2019). Development of augmented reality-based interactive multimedia to improve critical thinking skills in science learning. International Journal of Instruction, 12(4), 331-344. https://doi.org/10.29333/iji.2019.12421a

Trust, T. (2015). Deconstructing an Online Community of Practice: Teachers' Actions in the Edmodo Math Subject Community. Journal of Digital Learning in Teacher Education, 31(2), 73-81. https://doi.org/10.1080/21532974.2015.1011293

Trust, T. (2017). Motivation, Empowerment, and Innovation: Teachers' Beliefs About How Participating in the Edmodo Math Subject Community Shapes Teaching and Learning. Journal of Research on Technology in Education, 49(1-2), 16-30. https://doi.org/10.1080/15391523.2017.1291317 
EDUMATIKA: Jurnal Riset Pendidikan Matematika

e-ISSN 2620-8911

Volume 4, Issue 1, May 2021

Wijayanti, R., Hasan, B., \& Loganathan, R. K. (2018). Media comic math berbasis whiteboard annimation dalam pelajaran matematika. Jurnal Riset Pendidikan Matematika, 5(1), 53-63. https://doi.org/10.21831/jrpm.v5i1.19207

Wrahatnolo, T., Wibawa, S. C., \& Wahono, A. (2019). The implementation of Edmodo using cooperative learning model in Operating System. Advan. Soc. Sci. Edu. and Hum. Res., 299, 396-399. https://doi.org/10.2991/ictvet-18.2019.90 